\title{
NITROGEN 15 ABUNDANCE IN PROTEIN FRACTIONS OF BEANS FERTILIZED WITH $\left({ }^{15} \mathrm{NH}_{4}\right)_{2} \mathrm{SO}_{4}$
}

\author{
Saula Goulart Chaud ${ }^{1,3}$; Admar Costa de Oliveira" ${ }^{1 *}$; Paulo César Ocheuze Trivelin² \\ ${ }^{1}$ Depto. de Planejamento Alimentar e Nutrição - UNICAMP/FEA, C.P. 6121 - CEP: 13083-970 - Campinas, SP. \\ ${ }^{2}$ Lab. de Isótopos Estáveis - USP/CENA, C.P. 96 - CEP: 13400-970 - Piracicaba, SP. \\ ${ }^{3} \mathrm{CNPq}$ Fellow. \\ *Corresponding author <admarco@fea.unicamp.br>
}

\begin{abstract}
Studies evaluating the protein nutritive value of beans labelled with ${ }^{15} \mathrm{~N}$, using nitrogen balance and the quantitation of faecal and urinary endogenous nitrogen, determined by isotopic dilution, have been extensively used. The objective of this research was to verify if the isotopic labelling of raw, freeze dried beans (Phaseolus vulgaris L., cultivar Piratã 1) with 1.394 atoms $\%{ }^{15} \mathrm{~N}$, resulted in the same abundance of the whole flour and of the protein fractions extracted from the beans with $0.5 \mathrm{~mol} \mathrm{~L}^{-1} \mathrm{NaCl}$. The isotopic abundance found in the whole bean flour, in the protein extract, in the globulin and albumin fractions were respectively: $1.394 \pm 0.011 ; 1.403 \pm 0.012 ; 1.399 \pm 0.007$ and $1.399 \pm 0.028$ atoms $\%$ of ${ }^{15} \mathrm{~N}$, presenting no difference $(P>$ $0.05)$. However, a difference was found $(P<0.05)$ between the above mentioned abundances and the isotopic abundance found in the nitrogen of the proteins in the extraction residue, which was $0.969 \pm 0.084$. Since the abundances did not differ, the protein nutritive indexes, such as digestibility and biological value, determined from the nitrogen balance and corrected for isotopic dilution, would not be affected by extracting the proteins from the beans with $0.5 \mathrm{~mol} \mathrm{~L}^{-1} \mathrm{NaCl}$. If working with the nitrogen balance of the residual proteins after extraction and even with the whole flours, these indexes could present incorrect values, since the isotopic labelling of the residual proteins was less than that of the protein fractions.
\end{abstract}

Key words: Phaseolus vulgaris L., stable isotopes, isotopic label, nutritive value, experimental nutrition

\section{ABUNDÂNCIA DE ${ }^{15} \mathrm{~N}$ EM FRAÇÕES PROTÉICAS DE FEIJÃO FERTILIZADO COM $\left({ }^{15} \mathrm{NH}_{4}\right)_{2} \mathrm{SO}_{4}$}

\begin{abstract}
RESUMO: Estudos para determinação do valor nutritivo da proteína de feijões marcados com ${ }^{15} \mathrm{~N}$, utilizando balanço de nitrogênio e quantificação de nitrogênio endógeno fecal e urinário, determinados por diluição isotópica, têm sido muito utilizados. O objetivo deste trabalho foi verificar se a abundância de ${ }^{15} \mathrm{~N}$ feijão cru e liofilizado (Phaseolus vulgaris L., cultivar Piratã 1), de 1,394 átomos \% de ${ }^{15} \mathrm{~N}$, era a mesma, na farinha integral do feijão, no extrato protéico e nas frações protéicas extraídas do feijão com $\mathrm{NaCl} 0,5 \mathrm{~mol} \mathrm{~L}^{-1}$. As abundâncias encontradas na farinha integral, extrato protéico e frações protéicas globulina e albumina foram, respectivamente: $1.394 \pm 0.011 ; 1.403 \pm 0.012 ; 1.399 \pm 0.007$ e $1.399 \pm 0.028$ átomos \% de ${ }^{15} \mathrm{~N}$, não apresentando diferença $(P>0,05)$. Entretanto, foi encontrada diferença $(P<0,05)$ entre as referidas abundâncias e aquela encontrada nas proteínas que permaneceram no resíduo da extração, que foi 0,969 \pm 0,084 átomos de ${ }^{15} \mathrm{~N}$. Uma vez que as marcações isotópicas não diferiram, pôde-se inferir que os índices de valor nutritivo de proteínas, como a digestibilidade ou valor biológico, determinados por balanço de nitrogênio e corrigidos por diluição isotópica, não serão afetados pela extração das proteínas do feijão com $\mathrm{NaCl} 0,5$ $\mathrm{mol} \mathrm{L}^{-1}$. No caso das proteínas residuais ou mesmo de farinhas integrais, estes índices podem apresentar valores incorretos, visto que a abundância de ${ }^{15} \mathrm{~N}$ das proteínas residuais foi menor.

Palavras-chave: Phaseolus vulgaris L., isótopos estáveis, marcação isotópica, valor nutritivo, nutrição experimental
\end{abstract}

\section{INTRODUCTION}

Radioactive carbon determinations in pods and seeds found by archaeologists in Aztec and Inca tombs, showed that the cultivation of beans must have been domesticated approximately 7,000 years ago in Central America, the center of its origin, and in the southern regions of the USA, Mexico and the north of South America (Kaplan, 1965). Beans were introduced into Europe in the XVI Century, and since then, have been an important crop in various parts of the world. In Brazil, beans are the protein base of the population's diet. The protein content of the various species of Phaseolus varies from 18 to $35 \%$. Given the high daily consumption of this legume, due to economic and cultural problems, it is clear that it is responsible for supplying a significant part of the protein, calories and other nutrients in the world population diet. However, the biological and nutritional value of the bean protein is limited by various factors: limiting amounts of sulphur amino acids, low digestibility and low biological availability of the limiting amino acids, and also by the presence of toxic proteins and other antinutritional factors, especially when raw or badly processed. 
Beans, despite their importance as a food and the problems connected with its use, have been inadequately studied, for example, in experimental nutrition studies using isotopic labelling with ${ }^{15} \mathrm{~N}$, in order to study the protein metabolism and nutritive index measurements. This research aimed to determine if the ${ }^{15} \mathrm{~N}$ abundance obtained in raw, freeze dried beans (Phaseolus vulgaris L., cultivar Piratã 1) by fertilization with $\left({ }^{15} \mathrm{NH}_{4}\right)_{2} \mathrm{SO}_{4}$, was the same as that obtained in the protein fractions obtained by extraction with $0.5 \mathrm{~mol} \mathrm{~L}^{-1} \mathrm{NaCl}$.

\section{MATERIAL AND METHODS}

Whole raw, freeze dried beans were isotopically labelled with 1.394 atoms $\%$ of ${ }^{15} \mathrm{~N}$, by soil and leaf fertilization with $\left({ }^{15} \mathrm{NH}_{4}\right)_{2} \mathrm{SO}_{4}$ containing 10 atoms $\%{ }^{15} \mathrm{~N}$ in excess. The beans were cultivated in pot incubators in Campinas, SP, Brazil. Beans were harvested in the dry state, then frozen and freeze dried, aiming to preserve the raw material and also to help in the grinding and extraction processes of the proteins, and subsequent analyses.

\section{Sample preparation}

Beans were ground to a 70 mesh flour and the proteins extracted from this flour using $0.5 \mathrm{~mol} \mathrm{~L}^{-1} \mathrm{NaCl}$ (Whitaker \& Sgarbieri, 1981). The flour plus 1\% polyvinylpolypyrrolidone (Sigma) were mixed with a 0.5 mol $\mathrm{L}^{-1} \mathrm{NaCl}$ solution in the proportion of $1: 6(\mathrm{w} / \mathrm{v})$. Initially the mixture was submitted to ultrasonic vibration (Bronwill ultrasonic vibrator, model Biosonik IV, with the fine spindle) for 4 minutes, and then agitated for 2 hours with the $\mathrm{pH}$ adjusted to 7.0 (Oliveira et al., 1987). The suspension was then centrifuged at $16,300 \times \mathrm{g}$ for $30 \mathrm{~min}$ at $4^{\circ} \mathrm{C}$ (Sorvall centrifuge model $\mathrm{RC}_{2}-\mathrm{B}$ ) and the supernatant dialysed, also at $\mathrm{pH} 7.0(\mathrm{MW}<8,000)$. The dialysed extract was frozen and freeze dried (VIRTIS freeze dryer model 10-146Mr-BA), thus producing a "bean protein extract". When a second centrifugation of the dialysed extract was carried out at $16,300 \times \mathrm{g}$ for 30 min at $4^{\circ} \mathrm{C}$, two fractions were separated according to their solubility: one insoluble in water called "globulin fraction" and the other, a water soluble fraction called "albumin fraction", both being frozen and subsequently freeze dried. Under these conditions and at $\mathrm{pH} 7.0$, Oliveira et al. (1987) showed that the globulin fraction obtained was relatively free of albumin, but that the albumin fraction was contaminated with some partially soluble globulins. Protein fractionation was carried out as shown in Figure 1. The extraction was carried out in triplicate, and a pool of each protein fraction collected in order to obtain greater amounts.

\section{Analytical methods}

Nitrogen was determined by the semi-micro Kjeldahl method (Cunnif, 1995) and protein as crude protein ( $\mathrm{N} \times 5.4$ ) (Mossé, 1990). Nitrogen 15 was determined in the whole flour and protein fractions from the titres obtained in the nitrogen determinations (Bremner, 1965; International Atomic Energy Agency, 1972). The available in vitro methionine liberated into the supernatant as a result of protein hydrolysis by pepsin and pancreatin (respectively incubating at $37^{\circ} \mathrm{C}$ for 2 hours at $\mathrm{pH}=7.0$ and 24 hours at $\mathrm{pH}=8.3$ ) either in the free form or in soluble peptides, was determined as the control, using a modification of the colorimetric method of McCarthy \& Sullivan (1941), as proposed by Genovese \& Lajolo (1993). To a $1.0 \mathrm{~mL}$ sample of the hydrolysate, $0.25 \mathrm{~mL}$ of $5 \mathrm{~mol} \mathrm{~L}^{-1} \mathrm{NaCl}, 25 \mu \mathrm{L}$ of $10 \%$ sodium nitroprussiate and $0.5 \mathrm{~mL}$ of $3 \%$ glycine was added, the medium being acidified by addition of $0.5 \mathrm{~mL} 85 \%$ phosphoric acid, and reading the absorbance at $520 \mathrm{~nm}$ after $5 \mathrm{~min}$ of reaction.

\section{Statistical analysis}

Data were analyzed by ANOVA, followed by Duncan's new multiple-range test to evaluate differences of the means (Duncan, 1955).

\section{RESULTS AND DISCUSSION}

The raw freeze dried bean flour presented a crude protein content of $20.6 \pm 0.04 \%$, which is in agreement with that found by Marquez \& Lajolo (1981), who reported a value of $21.1 \%$ crude protein for the same cultivar. Verifying the protein percentages in the protein fractions of the cultivar under study, separated according to their solubility characteristics, the values were $51.6 \%$ for the albumins and $58.1 \%$ for the globulins. For the protein extract and residue these protein values were $56.6 \%$ and $6.4 \%$ respectively. The values of grams of methionine liberated per $100 \mathrm{~g}$ protein during the in vitro hydrolysis of the raw flour and its protein fractions showed that the highest values were found for the protein extract and the globulin fraction, $0.41 \mathrm{~g} \mathrm{Met} / 100 \mathrm{~g}$, and the lowest for the whole flour, $0.30 \mathrm{~g}$ Met $/ 100 \mathrm{~g}$ protein. The albumin fraction showed an intermediate value, $0.37 \mathrm{~g} \mathrm{Met} / 100 \mathrm{~g}$ protein. These values are in accordance with those reported by Pompeu \& Roston (1988) who have found a level of bioavailable methionine of $0.39 \mathrm{~g} \mathrm{Met} / 100 \mathrm{~g}$ protein.

Table 1 - Isotopic ${ }^{15} \mathrm{~N}$ abundance in whole, raw, freeze dried bean flour (Phaseolus vulgaris L., cultivar Piratã 1) and their protein fractions. Beans fertilized with $\left({ }^{15} \mathrm{NH}_{4}\right)_{2} \mathrm{SO}_{4}$.

\begin{tabular}{ll}
\hline Material & Atoms $\%{ }^{15} \mathrm{~N}$ \\
\hline Whole flour & $1.394(0.011)^{1} \mathrm{a}$ \\
Protein extract & $1.403(0.012) \mathrm{a}$ \\
Globulin fraction & $1.399(0.070) \mathrm{a}$ \\
Albumin fraction & $1.399(0.028) \mathrm{a}$ \\
Residue & $0.969(0.084) \mathrm{b}$ \\
\hline
\end{tabular}

${ }^{1}$ The numbers in brackets correspond to the standard deviations of the results with respect to the mean presented (at least $n=3$ ). $a$, b Values with the same notation did not differ for Duncan's multiple-range test $(P>0.05)$. 


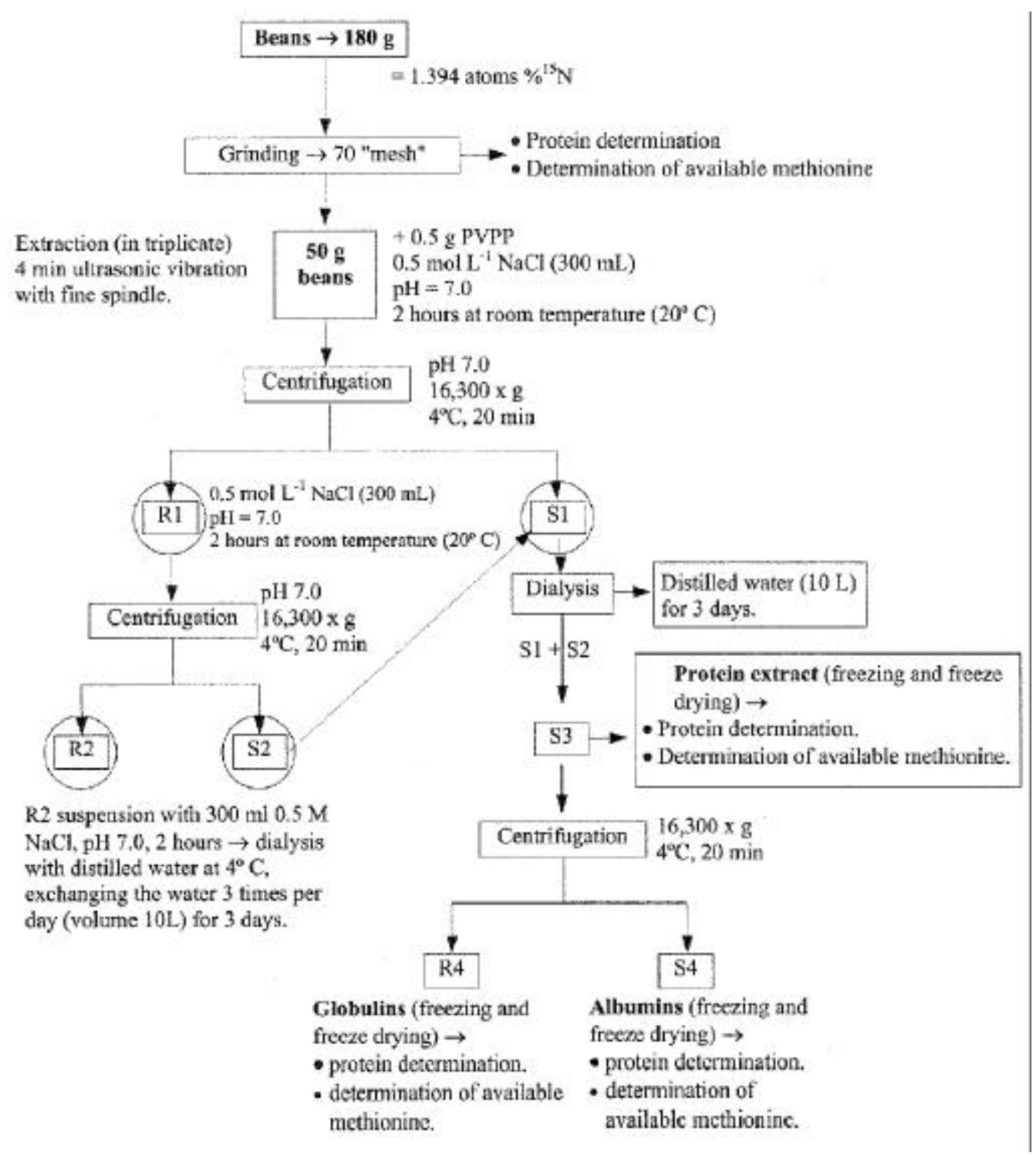

Figure 1 - Fractionation of proteins extracted from raw freeze dried beans (Phaseolus vulgaris L., cultivar Piratã 1) using 0.5 mol L-1 $\mathrm{NaCl}$

The isotopic abundances are shown in Table 1. The results for the whole flour, the protein extract and the isolated albumin and globulin fractions showed no difference $(P>0.05)$. However differences were found $(P<0.05)$ between the above cited abundances and the abundance of the nitrogen from the proteins of the extraction residue, which was $0.969 \pm 0.084$ atoms $\%{ }^{15} \mathrm{~N}$.

The results of biological experiments, in which the raw material used as the only protein source of a balanced diet to be used in nutritional assays is labelled with ${ }^{15} \mathrm{~N}$, should be viewed with caution, because the protein constituents of such raw materials can present non-homogenous abundances, at least in the case of this bean. Thus using the whole flour of the raw material as the only protein source of the diet, an isotopic dilution will occur in the faeces (Oliveira \& Sgarbieri, 1986;
Marquez \& Lajolo, 1991), which does not depend exclusively on the secretion and excretion of endogenous or corporal nitrogen by the animal used in the experiment. Those proteins which generally remain in the extraction residue, in the case of the present study, about $30 \%$ of the total protein of the beans, which present a relatively less intense abundance of ${ }^{15} \mathrm{~N}$ as compared to the extract and fractions obtained by differential solubility, are the main cause of this isotopic dilution. Thus, in this particular case the isotopic dilutions tend to present estimates of the secretions and excretions of the experimental animals superior to those really coming from the body, which could influence the calculations of the protein nutritive indexes. On the other hand, when the amounts of these residual proteins are small, for practical purposes, this influence can be neglected. 


\section{REFERENCES}

BREMNER, J.M. Isotope ratio analysis of nitrogen in nitrogen 15 tracer investigations. In: BLACK, C.A.; ENSMINGER, L.E.; CLARK, F.E. (Ed.) Methods of soil analysis. Madison: ASA, 1965. v.2, p.1265-1286.

CUNNIFF, P. (Ed.) Official methods of analysis of the AOAC. 16.ed. Arlington: AOAC International, 1995. cap.39, p.7-8

DUNCAN, D.B. Multiple-range and multiple F tests. Biometrics, v.11, p.1-42, 1955.

GENOVESE, M.I.; LAJOLO, F.M. Utilization of the colorimetric method of McCarthy \& Sullivan for the determination of biodegradable methionine in bean proteins (Phaseolus vulgaris L.) Arquivos de Biologia e Tecnologia, v.36, p.545-566, 1993.

INTERNATIONAL ATOMIC ENERGY AGENCY - IAEA. Tracer manual on crops and soils. Vienna, 1972. (Bulletin Series, 172).

KAPLAN, L. Archeology and domestication in American Phaseolus (beans). Economic Botany, v.19, p.358-368, 1965.

MARQUEZ, U.M.L.; LAJOLO, F.M. Composition and digestibility of albumin, globulins, and glutelins from Phaseolus vulgaris. Journal of Agricultural and Food Chemistry, v.29, p.1068-1074, 1981.

MARQUEZ, U.M.L.; LAJOLO, F.M. In vivo digestibility of bean (Phaseolus vulgaris L.) protein: The role of endogenous protein. Journal of Agricultural and Food Chemistry, v.39, p.1211-1215, 1991.
MCCARTHY, T.E.; SULLIVAN, M.X. A new and highly specific colorimetric test for methionine. The Journal of Biological Chemistry, v.141, p.871$876,1941$.

MOSSÉ, J. Nitrogen to protein conversion factor for ten cereals and six legumes or oilseeds. A reappraisal of its definition and determination. Variation according to species and to seeds protein content. Journal of Agricultural and Food Chemistry, v.38, p.18-24, 1990.

OLIVEIRA, A.C.; SGARBIERI, V.C. The influence of rat endogenous nitrogen excretion on the assessment of bean protein quality. Journal of Nutritional Science and Vitaminology, v.32, p.425-436, 1986.

OLIVEIRA, A.C.; SAWAZAKI, H.E.; GALEAZZI, M.A.M. Extração, caracterização parcial e aspectos nutricionais das proteínas do feijão Carioca 80 (Phaseolus vulgaris L.) Archivos Latinoamericanos de Nutrición, v.37, p.88-100, 1987.

POMPEU, A.S.; ROSTON, A.J. Feijoeiro: Carioca 80 (sem halo). Campinas: CATI, 1988 (Comunicado Técnico, 74).

WHITAKER, J.R.; SGARBIERI V.C. Purification and composition of the trypsin - chymotrypsin inhibitors of Phaseolus vulgaris $\mathrm{L}$. var. Rosinha $\mathrm{G}_{2}$. Journal of Food Biochemistry, v.5, p.197-213, 1981.

Received June 29, 2001 